\title{
Fabrication and biocompatibility of a porous bioglass ceramic in a $\mathrm{Na}_{2} \mathrm{O}-\mathrm{CaO}-\mathrm{SiO}_{2}-\mathrm{P}_{2} \mathrm{O}_{5}$ system
}

\author{
Feng-Huei Lin, Yi-You Huang, *Min-Hsiung Hon and *Shih-Ching Wu \\ Center for Biomedical Engineering, College of Medicine, National Taiwan University, \\ Taipei, and *Department of Materials Engineering, National Cheng-Kung University, \\ Tainan, Taiwan, Republic of China
}

Received August 1990, accepted November 1990

\begin{abstract}
A porous bioglass ceramic was prepared from a finely pulverized bioglass powder mixed with particles of two sizes (5 and $500 \mu \mathrm{m})$ of $30 \%$ by weight with the foaming agent polyethylene glycol $4000\left(\mathrm{HO}\left(\mathrm{C}_{2} \mathrm{H}_{4} \mathrm{O}\right) \mathrm{nH}\right)$. The batch composition of the bioglass was $\mathrm{Na}_{2} \mathrm{O} 72 \%, \mathrm{CaO} 28 \%$, $\mathrm{SiO}_{2} 50 \%$ and $\mathrm{P}_{2} \mathrm{O}_{5} 10 \%$ by weight. The specimens, formed by pressing, were sintered in a high temperature furnace. In this study we are concerned with the preparation and microstructure of the material and its performance in biological tests. The microstructure and crystalline phases of the material were investigated by differential thermal analysis, $X$-ray diffraction analysis, transmission electron microscopy and scanning electron microscopy. In a biomedical examination, it was shown that the porous material was compatible with animal tissues. The microstructure of the implant indicated that newly grown bone interlocked well with the glass ceramic and that macropores and micropores were distributed uniformly in the material, which provided channels for bone ingrowth and improved the microscopic bioresorption.
\end{abstract}

Keywords: Bioglass ceramics, biocompatibility, microstructure

\section{INTRODUCTION}

In the past, metallic materials were used for bone and joint replacement, but the problems of corrosion troubled researchers. In 1960, fine ceramics such as zirconia and alumina were used because of their good biocompatibility and high mechanical strength. However, they do not form a tight chemical bond with bone and mechanical locking is required to fix them to bone, which is liable to loosen over a long period of implantation ${ }^{1,2}$.

Since 1970, calcium phosphate systems, in particular hydroxyapatite, have been the subject of intensive investigation for medical implants, because they are usually bioactive and can bond directly to the bony tissue. Unfortunately, their lower mechanical strength is the reason for their failure to be adopted in clinical practice. A promising solution to this problem is to produce a glass ceramics from calcium phosphate in crystalline phase, which in modern medicine have become known as 'bioglasses and bioglass ceramics' $^{\text {'3-5. }}$.

At present, there is some in vivo evidence to suggest that the macropore structure of the implants is better, with regard to bone ingrowth and bioresorption, than the dense structure. One suggestion, put forward by de Groot ${ }^{6}$, is that the micropores (about $5 \mu \mathrm{m}$ ) in these structures determine the rate of bioresorption.

Correspondence and reprint requests to: Feng Huei Lin

(C) 1991 Butterworth-Heinemann for BES 0141-5425/91/040328-07

328 J. Biomed. Eng. 1991, Vol. 13, July
Most currently investigated porous implants are fabricated to have macropores in the range of 100$400 \mu \mathrm{m}$, so as to allow bone ingrowth; this requirement emerged from the studies of Klawitter and Hulbert ${ }^{7}$. However, their methods of fabrication rely on the decomposition of hydrogen peroxide to produce calcium phosphate replicas of a marine coral structure, which is a pore-filled structure but lacks micropores, and induce changes in the chemical composition of the implants.

The main work of this study is to use the decomposition of polyethylene glycol 4000 with particles of two sizes to generate the macropore and micropore structure in $\mathrm{Na}_{2} \mathrm{O}-\mathrm{CaO}-\mathrm{SiO}_{2}-\mathrm{P}_{2} \mathrm{O}_{5}$ system bioglass ceramics. The bioglass preparation, crystalline condition and biocompatibility of the material are also described.

\section{EXPERIMENTAL PROCEDURES}

\section{Material preparation}

Samples of glass were made by melting batches of approximately $100 \mathrm{~g}$ in a platinum crucible at a temperature of $140^{\circ} \mathrm{C}$ for 1 hour. The nominal composition of each batch was $\mathrm{Na}_{2} \mathrm{O} 12 \%, \mathrm{CaO} 28 \%$, $\mathrm{SiO}_{2} 50 \%$ and $\mathrm{P}_{2} \mathrm{O}_{5} 10 \%$ by weight, using reagent grade $\mathrm{Na}_{2} \mathrm{CO}_{3}, \mathrm{CaCO}_{3}, \mathrm{Ca}_{3}\left(\mathrm{PO}_{4}\right)_{2}$ and $\mathrm{SiO}_{2}$. Tricalcium phosphate was normally used as the source of $\mathrm{P}_{2} \mathrm{O}_{5}$. The melt was poured on to a stainless steel plate, pressed to a thickness of approximately $5 \mathrm{~mm}$, 
and then quickly annealed at $550^{\circ} \mathrm{C}$ and held for 2 hours to remove residual stress.

The glass plate was pulverized into grains of about $5 \mu \mathrm{m}$ using a Spex 8000 alumina ball mill. The glass powder, mixed with polyethylene glycol 4000 in particle sizes of 5 and $500 \mu \mathrm{m}$ to produce macroand micro-pore structures after decomposition, was pressed into a disc $10 \mathrm{~mm}$ in diameter and $5 \mathrm{~mm}$ in thickness under a hydrostatic pressure of $270 \mathrm{MPa}$. The glass powder compact was placed on a platinum sheet and heated to various temperatures at a rate of $5^{\circ} \mathrm{C} \mathrm{min}^{-1}$ in a $\mathrm{SiC}$ furnace, then removed immediately after reaching the appropriate temperature, and allowed to cool in air.

\section{Measurements}

Differential thermal analysis of the glass powder was made with a Rigaku thermoflex TG-8110 at a rate of $5^{\circ} \mathrm{C} \mathrm{min}-1$. The nature and content of crystals precipitated in the samples were determined by powder $\mathrm{X}$-ray diffraction analysis. In the determination of crystal content, relative intensities of non-crystalline scattering, (130) reflection of $\mathrm{Na}_{2} \mathrm{Ca}_{3} \mathrm{Si}_{6} \mathrm{O}_{16}$ and (201) reflection of $\beta$ - $\mathrm{Ca}_{2} \mathrm{P}_{2} \mathrm{O}_{7}$ were used. The microstructure of the sample was observed under a Hitachi S450 scanning electron microscope after being coated with a thin gold film. Specimens for transmission electron microscopy were obtained from a massive sample by slicing with a diamond on the dimple grinder to a thickness of $30 \mu \mathrm{m}$ and then cutting further by ion-beam milling. The electron diffraction pattern from the selected area was recorded on a photographic plate.

Porosity of the samples was determined by measuring the bulk and true density using Achimedean and pycnometer methods, respectively. The immersion liquid was pure water.

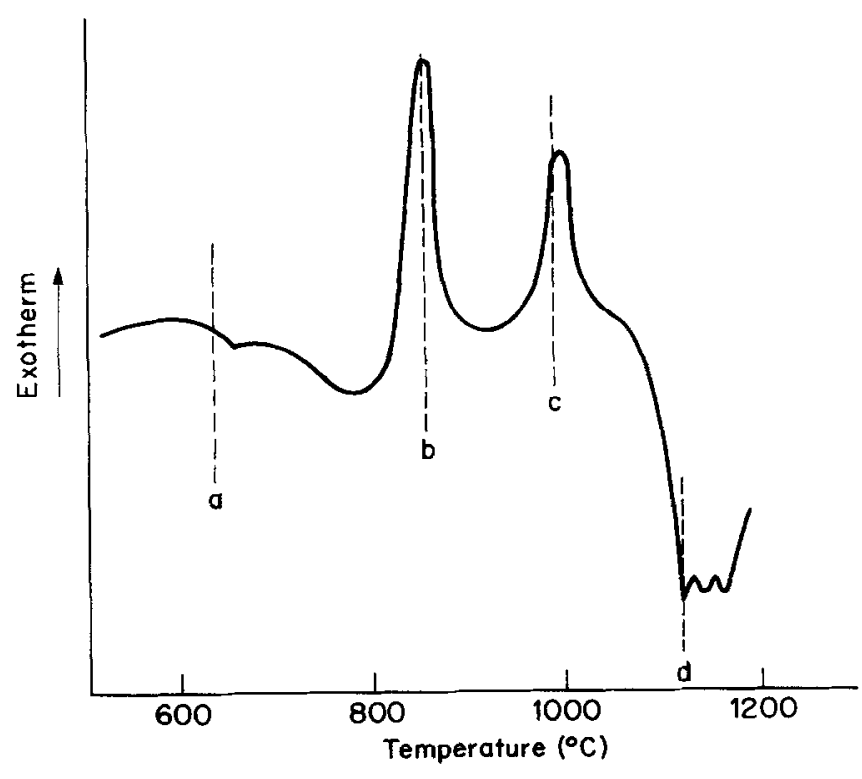

Figure 1 Differential thermal analysis (DTA) curve of the glass powder. a: Annealing point; b: exothermic peak due to formation of $\beta-\mathrm{Ca}_{2} \mathrm{P}_{2} \mathrm{O}_{7}$; c: exothermic peak for $\mathrm{Na}_{2} \mathrm{Ca}_{3} \mathrm{Si}_{6} \mathrm{O}_{16}$ crystallization; $\mathrm{d}$; endothermic peak due to the first melting

\section{Evaluation of biocompatibility and histology}

Two biological tests were performed on each specimen $^{8,9}$.

1. The rat shoulder test was used to estimate the biological compatibility of the specimen. The Wistar rats used in the test were 6 -weeks old and $100 \mathrm{~g}$ in weight at the start of the experiment. The implants were moistened with saline and inserted in the rat shoulder for 1 month; at the end of the test period, the rats were perfused with $10 \%$ formalin and the skin in contact with the implants was dissected out and embedded in paraffin. Sections were stained with haematoxylin and eosin for observation.

2. Two-month-old New Zealand rabbits were used for histological evaluation. The rabbits were anaesthetized by intravenous nembutal. Holes were

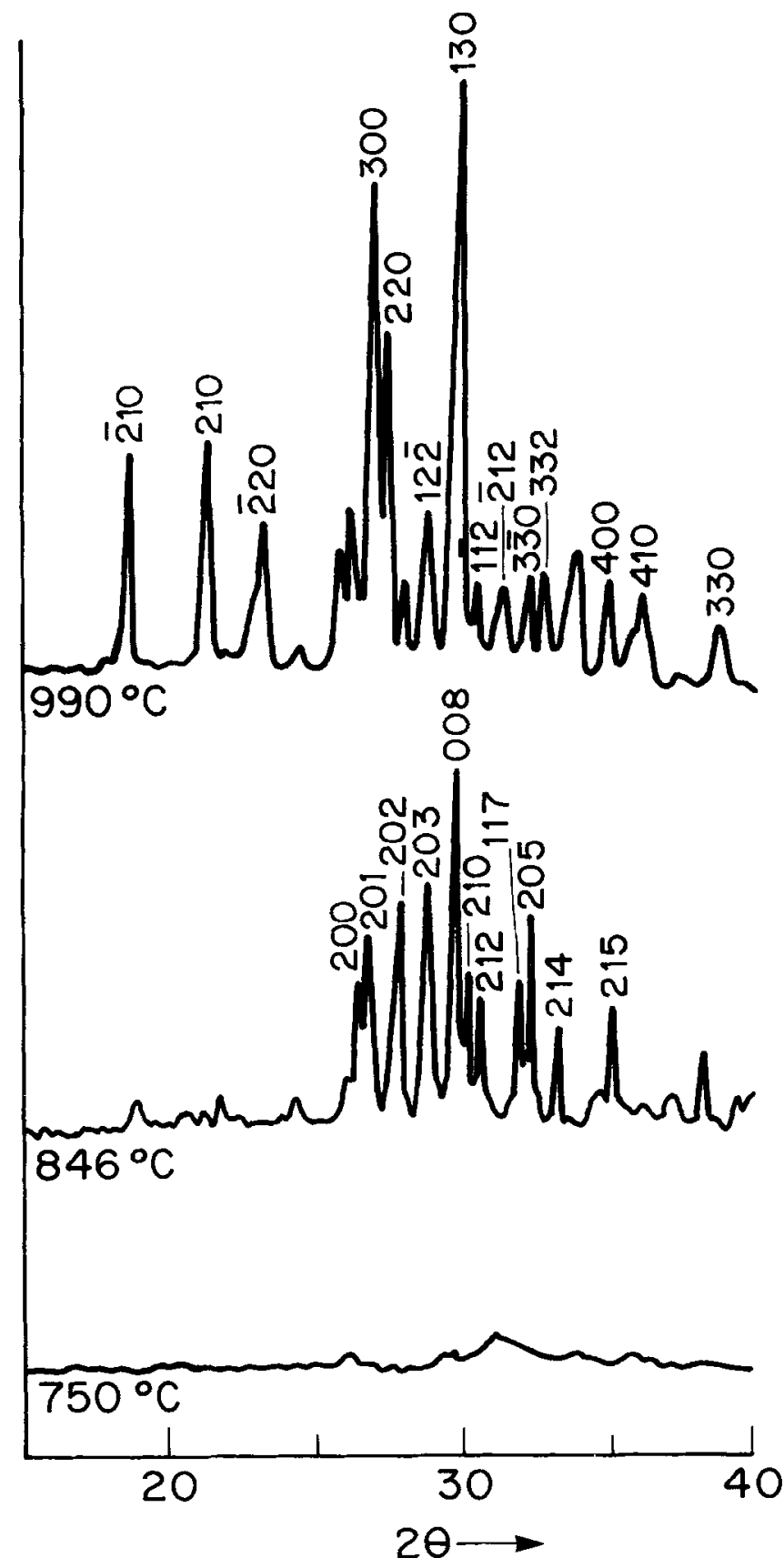

Figure $2 \mathrm{X}$-ray diffraction curves of the glass heated at $750^{\circ} \mathrm{C}$, $846^{\circ} \mathrm{C}$ and $990^{\circ} \mathrm{C}$, respectively 


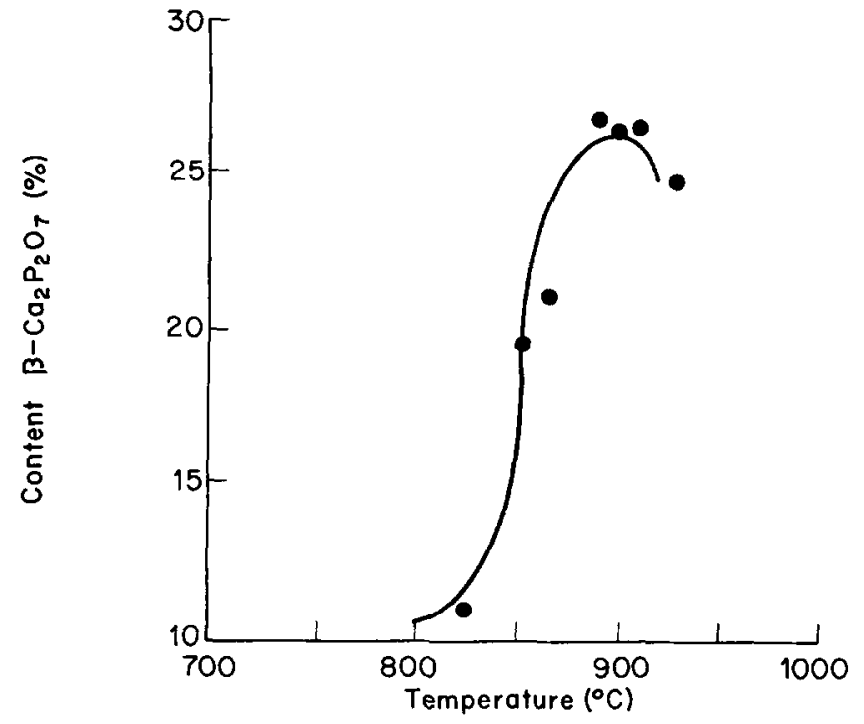

Figure 3 Variation in the content of $\beta-\mathrm{Ca}_{2} \mathrm{P}_{2} \mathrm{O}_{7}$ in the glass ceramic with the sintering temperature

drilled in the femur with a dental drill, which was cooled with sterile physiological saline, and $2.5 \mathrm{~mm}$ diameter $\times 6 \mathrm{~mm}$ long cylinders of implant specimen were placed in the holes; the periosteum and the muscle layer were sutured with a biodegradable thread. After implantation for 3 months, the rabbits were sacrificed and the femurs with implants were examined by scanning electron microscopy. The femur was soaked in a $1 \mathrm{M}$ phosphate buffer with $10 \%$ ethylene diaminotetraacetic acid and embedded in paraffin. Microtome-

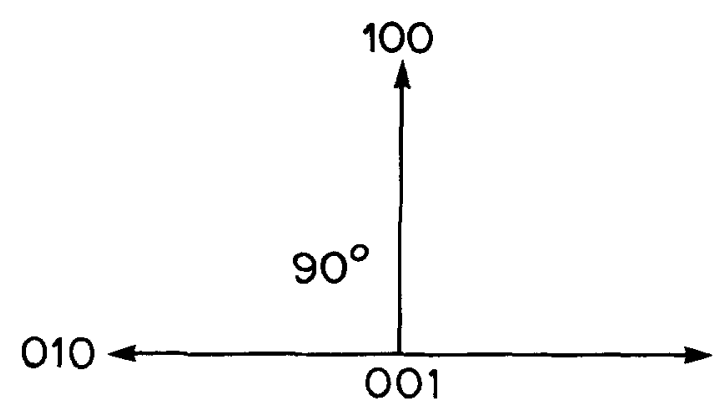

a

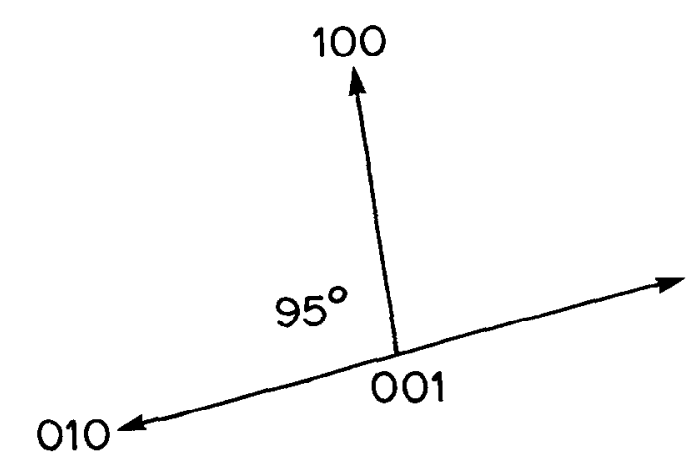

b

Figure 5 Electron diffraction patterns of the areas $\mathrm{A}$ and $\mathrm{B}$ indicated in Figure 6. a, (001) Zone of $\beta$ - $\mathrm{Ca}_{2} \mathrm{P}_{2} \mathrm{O}_{7} ; \mathbf{b},(001)$ zone of $\mathrm{Na}_{2} \mathrm{Ca}_{3} \mathrm{Si}_{6} \mathrm{O}_{16}$

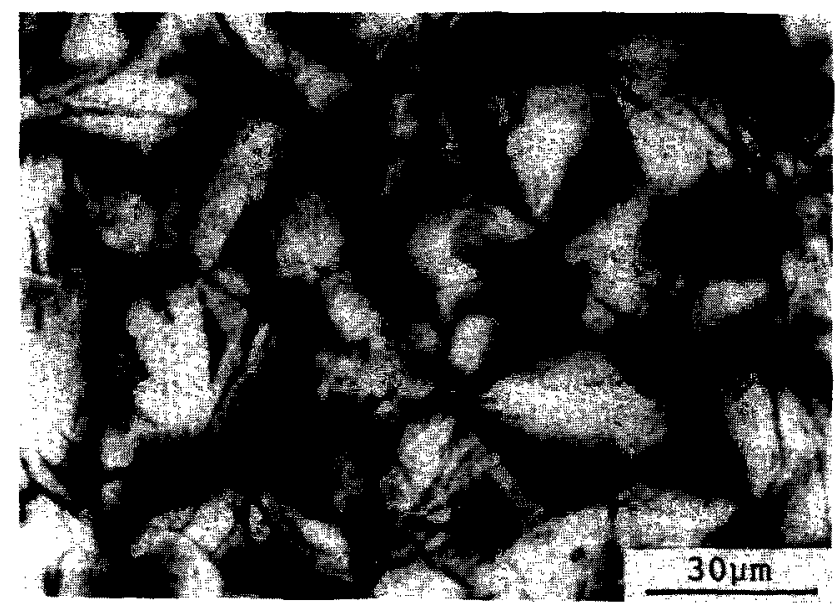

Figure 4 Optical micrograph of the glass compact sintered at $900^{\circ} \mathrm{C}$ for $80 \mathrm{~min}$

cut $10 \mu \mathrm{m}$ thick sections were coloured with iron haematoxylin eosin for optical microscopc examination.

\section{RESULTS AND DISCUSSION}

\section{Differential thermal analysis (DTA) and X-ray diffraction analysis}

Figure 7 shows a DTA curve of the parent glass powder. The crystalline phases are detected when the samples are heated to their exothermal peaks at temperatures of $846^{\circ} \mathrm{C}$ and $990^{\circ} \mathrm{C}$. The endothermal peaks observed above $1120^{\circ} \mathrm{C}$ correspond to the melting point of the glass ceramic.
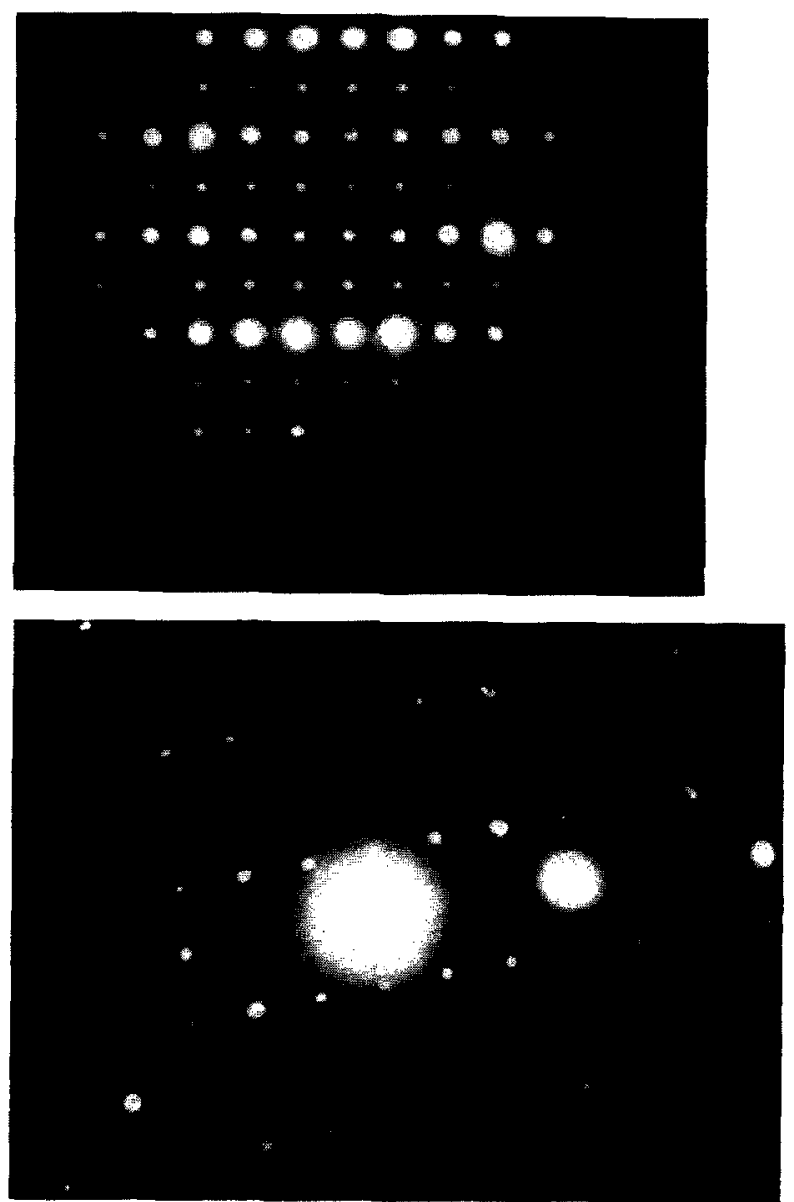
During the heating of the glass, samples were taken at different temperatures for $\mathrm{X}$-ray diffraction study. It was found that the glass precipitates $\beta-\mathrm{Ca}_{2} \mathrm{P}_{2} \mathrm{O}_{7}$ crystals at $846^{\circ} \mathrm{C}$ and mixed crystals appear of $\beta-\mathrm{Ca}_{2} \mathrm{P}_{2} \mathrm{O}_{7}$ and $\mathrm{Na}_{2} \mathrm{Ca}_{3} \mathrm{Si}_{6} \mathrm{O}_{16}$ at $990^{\circ} \mathrm{C}$ (Figure 2).

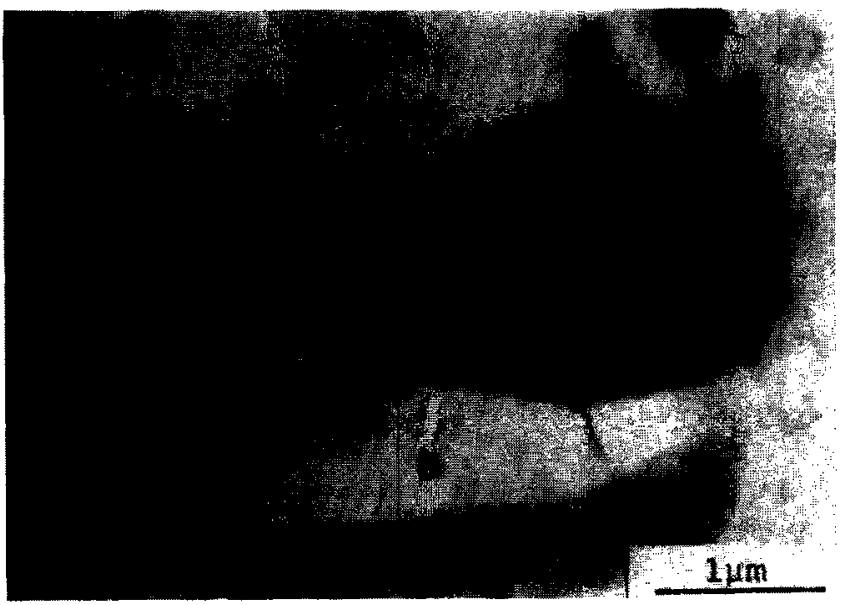

Figure 6 Tissue electron microscopy of the photograph of the glass heated at $900^{\circ} \mathrm{C}$ for $80 \mathrm{~min}$. $\mathrm{A}, \beta-\mathrm{Ca}_{2} \mathrm{P}_{2} \mathrm{O}_{7} ; \mathrm{B}, \mathrm{Na}_{2} \mathrm{Ca}_{3} \mathrm{Si}_{6} \mathrm{O}_{16}$
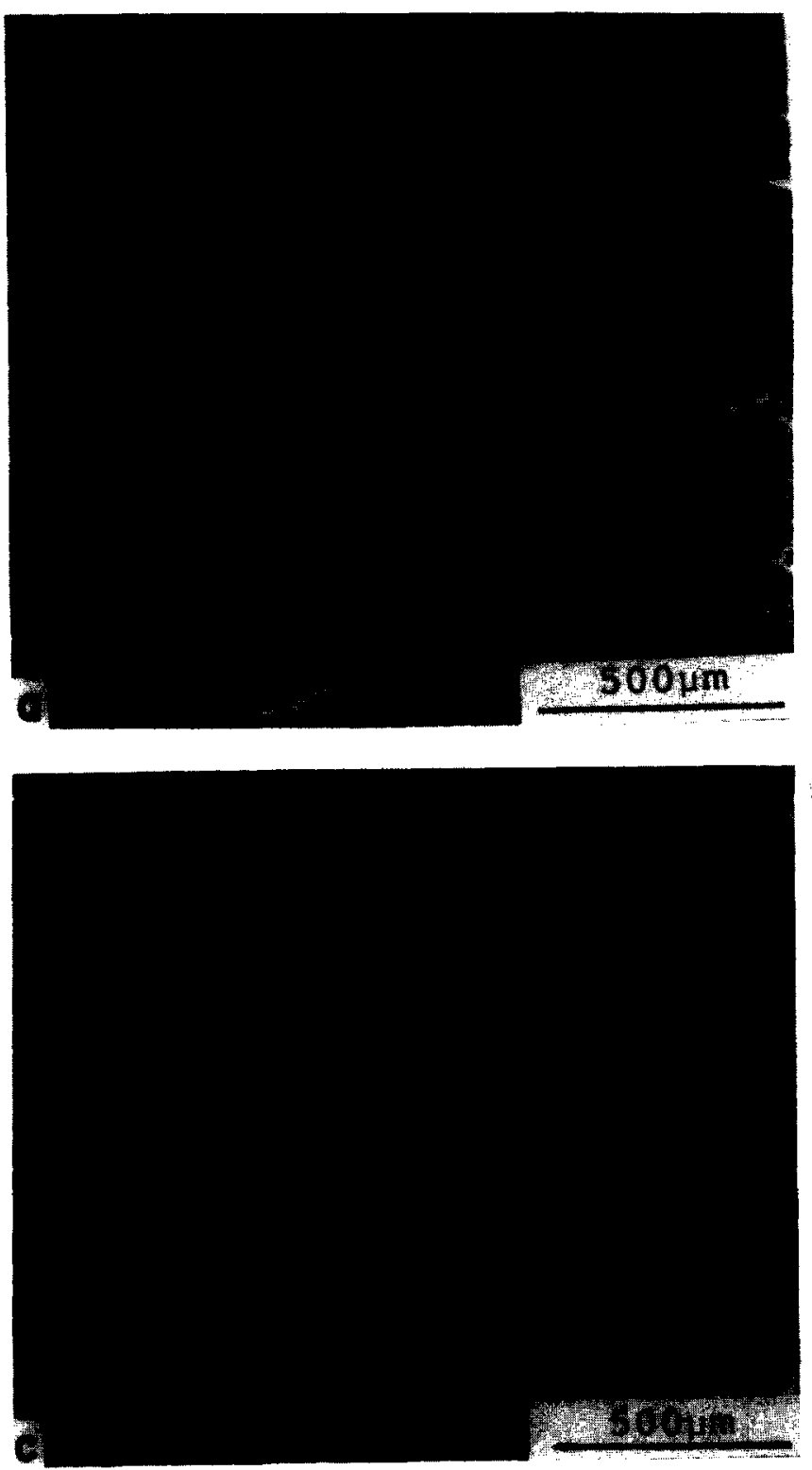

When the temperature was raised to $1120^{\circ} \mathrm{C}$, the glass melted. At temperatures below $750^{\circ} \mathrm{C}$, the glass appears to have no characteristic diffraction peaks, which means that the sample remains mainly in its glassy state.

Dellemagne and Melon ${ }^{10}$ discovered that $\mathrm{Ca}^{2+}$ and $\mathrm{PO}_{4}^{-3}$ are the main inorganic constituents of human bone. Hydroxyapatite and whitlockite are the main mineral components of bone and can be derived from $\mathrm{Ca}_{2} \mathrm{P}_{2} \mathrm{O}_{7}, \mathrm{CaP}_{2} \mathrm{O}_{6}$ or amorphous calcium phosphates. Moreover, $\mathrm{Ca}_{2} \mathrm{P}_{2} \mathrm{O}_{7}$ can take part in bone growth and act also as a substrate for the growth of new bone. Thus, the content of $\beta-\mathrm{Ca}_{2} \mathrm{P}_{2} \mathrm{O}_{7}$ in the material is of considerable importance in biological texture and prosthetic application. The intensity of the (201) peak shown in Figure 2 is used to determine the amount of $\beta-\mathrm{Ca}_{2} \mathrm{P}_{2} \mathrm{O}_{7}$ in the glass ceramic, and is seen to vary with the sintering temperature of the glass compact (Figure 3). It is found that more $\beta$ $\mathrm{Ca}_{2} \mathrm{P}_{2} \mathrm{O}_{7}$ crystals are precipitated in the material at $900^{\circ} \mathrm{C}$. The choice of temperature for sintering glass compact requires consideration of the $\beta-\mathrm{Ca}_{2} \mathrm{P}_{2} \mathrm{O}_{7}$ content of the material in contact with biological tissue after implantation.
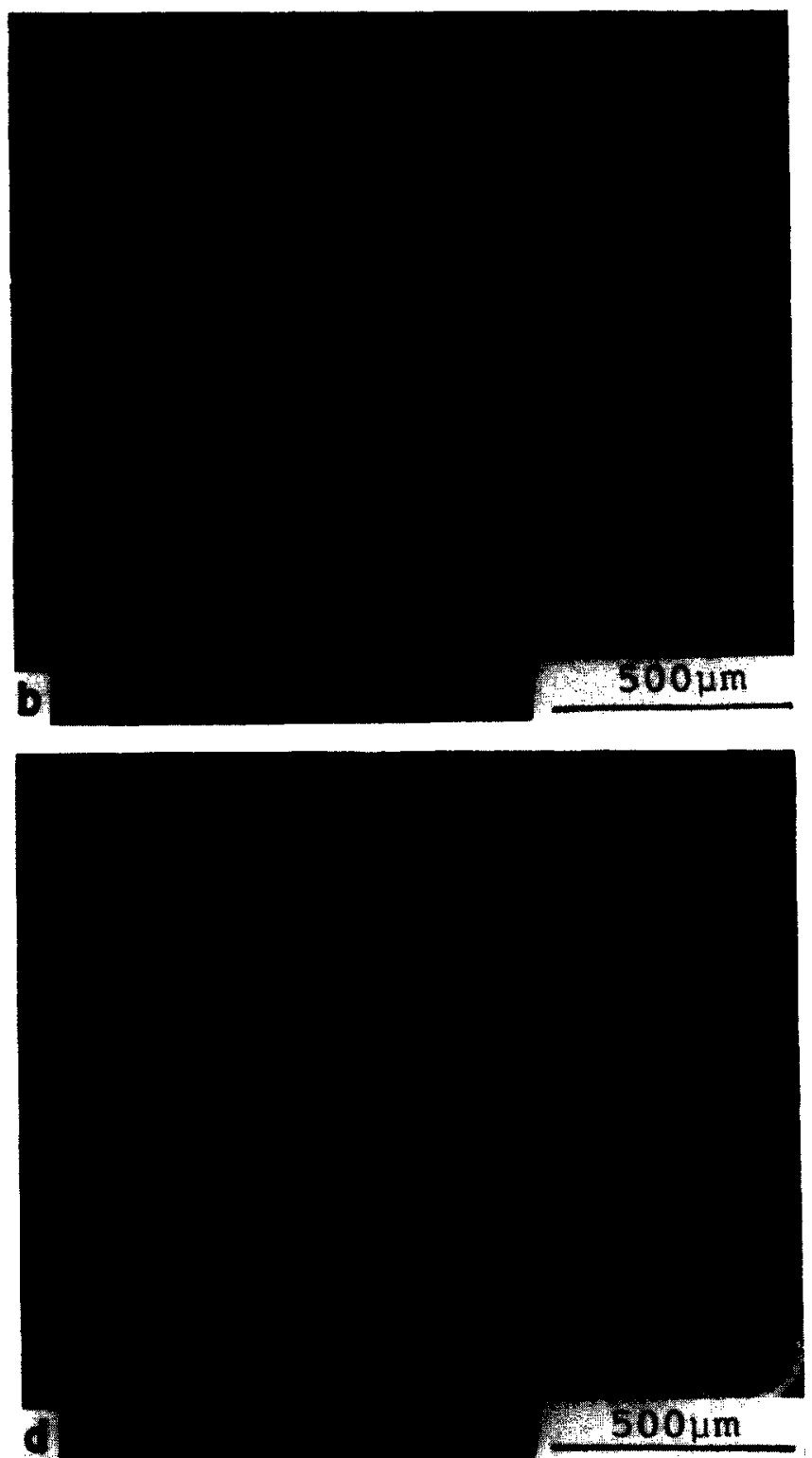

Figure $7 \mathrm{SEM}$ micrographs of the macropores in the specimen after heating at $900^{\circ} \mathrm{C}$ for $\mathrm{a}, 20 \mathrm{~min} ; \mathrm{b}, 40 \mathrm{~min} ; \mathrm{c}, 60 \mathrm{~min} ; \mathrm{d}, 80 \mathrm{~min}$ 


\section{Microstructure of the glass ceramic}

The optical photograph of the glass heated at $900^{\circ} \mathrm{C}$ for $80 \mathrm{~min}$ is shown in Figure 4 . It exhibits a uniform microstructure with a mean grain size of $30-40 \mu \mathrm{m}$. By estimating the refractive index using a polarizing microscope and an oil immersion method, the crystals can be distinguished from the glassy phase. By observing the microstructure of the sintered specimen, it is found that the crystalline phases bind closely to the glass phase. Using the diffraction patterns of selected areas in Figure 5, the incorporation of the $\beta$-Ca $\mathrm{Ca}_{2} \mathrm{P}_{2} \mathrm{O}_{7}$ crystals in the $\mathrm{Na}_{2} \mathrm{Ca}_{3} \mathrm{Si}_{6} \mathrm{O}_{16}$ grains can be observed under transmission electron microscopy (Figure 6).

After the decomposition of polyethylene glycol 4000 (added to the material in two particle sizes of 5 and $500 \mu \mathrm{m})$, the macro- and micropores in porous glass ceramic are shown in Figures 7 and 8 , respectively. The decrease in size of the macropores with sintering time is shown in Figure 9. In the sintering process, there are two procedures to reduce the system free energy as the driving force for densification: (1) grain coarsening, and (2) decreasing the

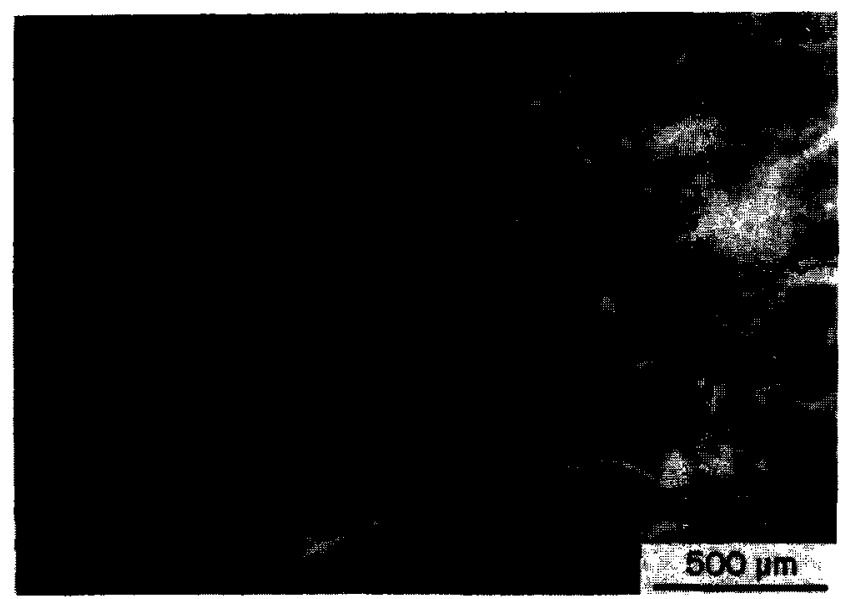

Figure 8 Scanning microscopy micrograph of the micropores in the material

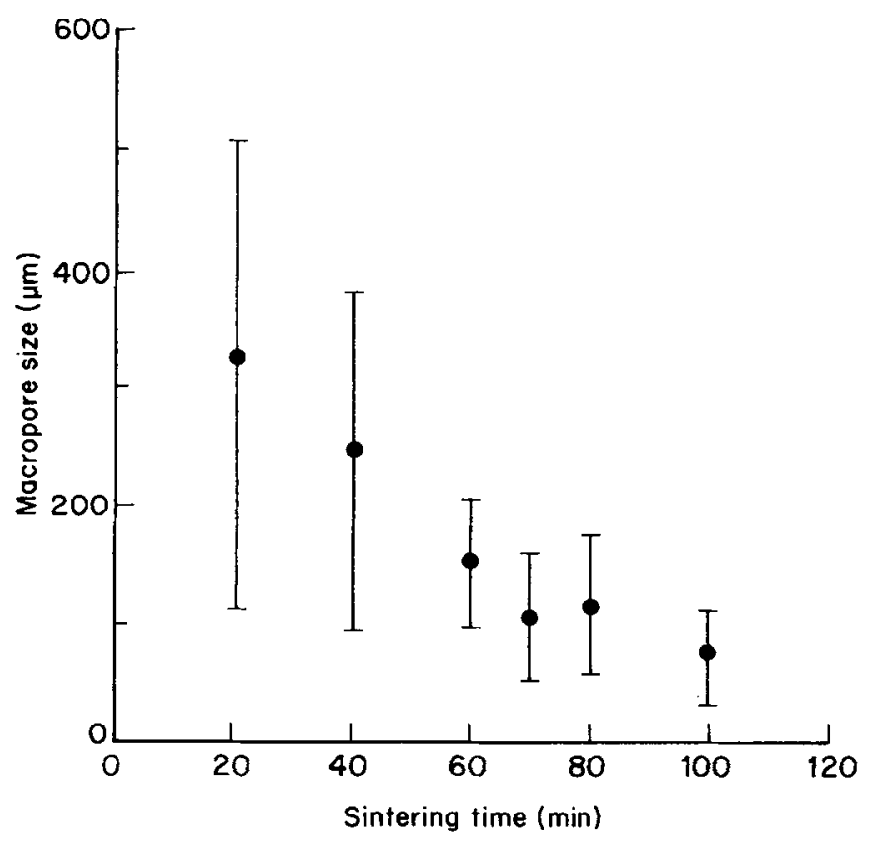

Figure 9 Dependence of the size of macropores on sintering time

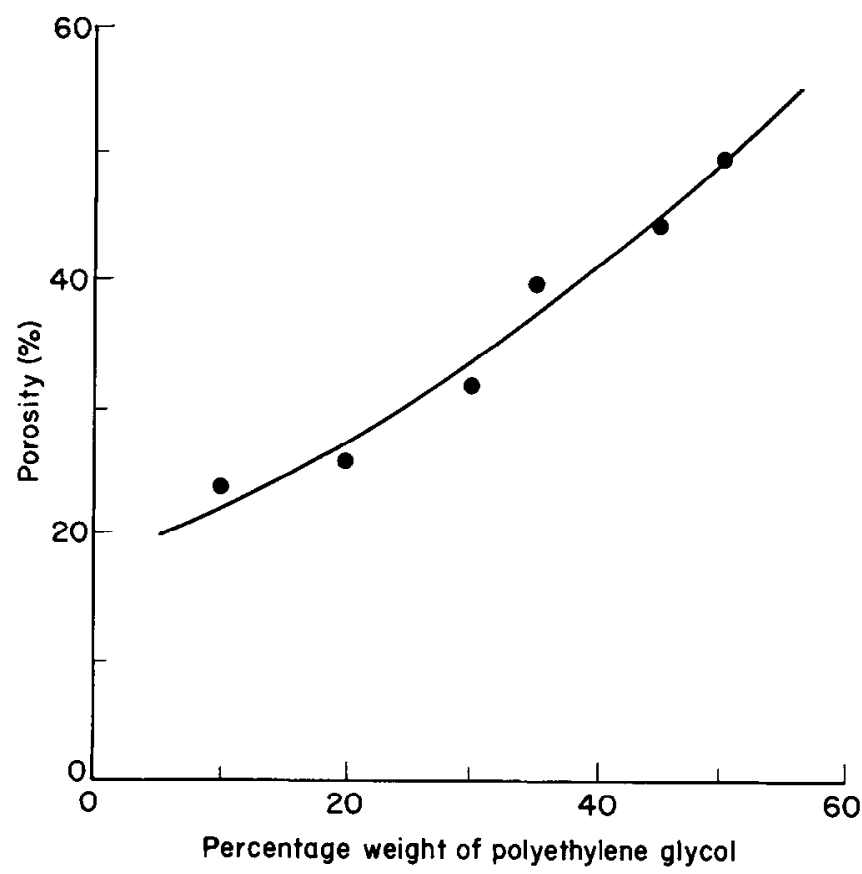

Figure 10 Curve relating polyethylene glycol to the porosity of the material after hetig t $900^{\circ} \mathrm{C}$ for $80 \mathrm{~min}$

solid-vapour interface ${ }^{11}$. It would seem that the second procedure should diminish the size of macropores in the material as the densification process of the glass compact proceeds. Instead, the size of

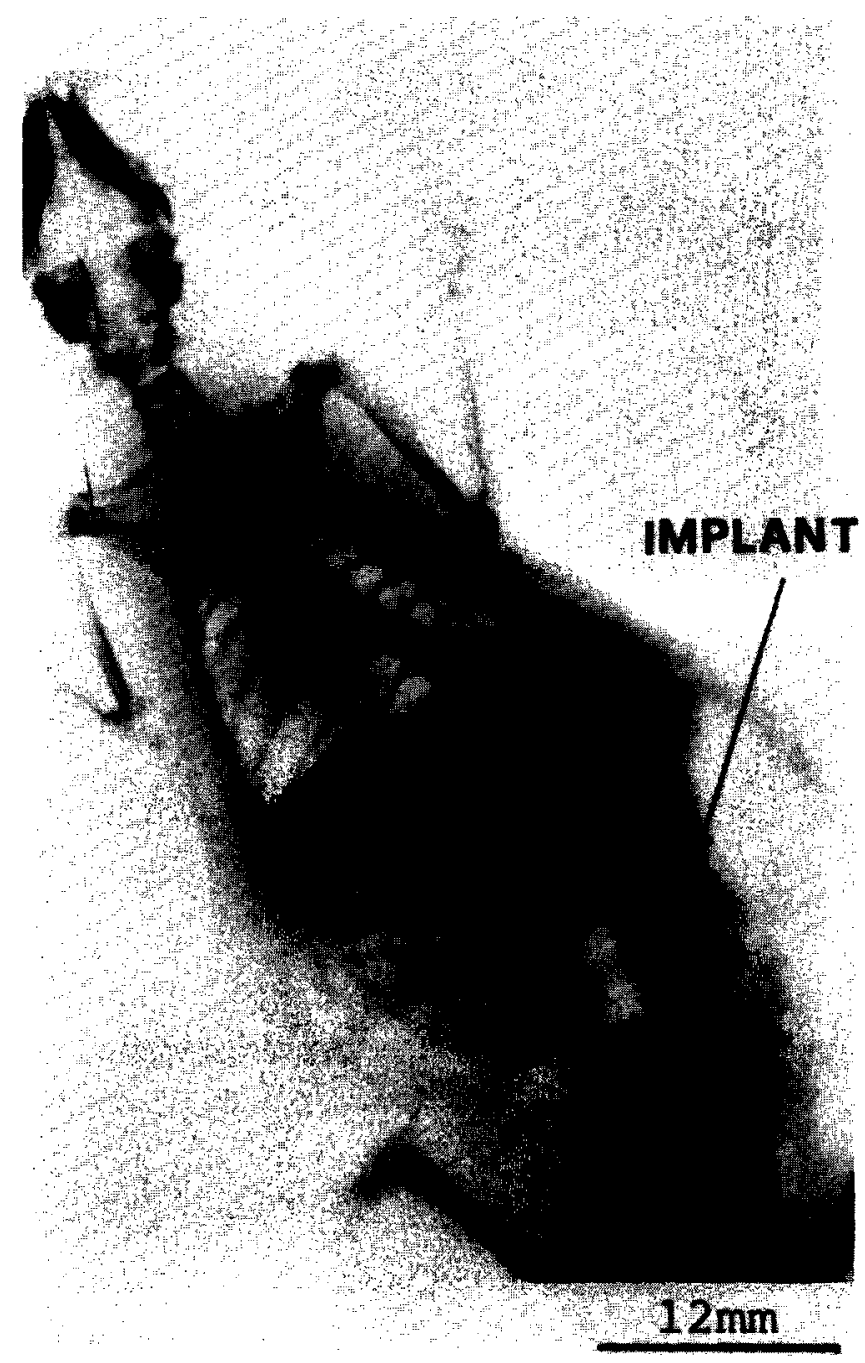

Figure $11 \mathrm{X}$-ray photograph of the implant in the rat shoulder 
micropores in the material shows no significant change during the sintering process. The authors suggest that the diminishing macroporosity is the dominant process for densification in porous glass ceramic. To meet the requirement for bone ingrowth, macropores in the size range $100-200 \mu \mathrm{m}$ were fabricated. As shown in Figure 7, porous ceramic with macropores in this range could be produced after heating the glass compact at $900^{\circ} \mathrm{C}$ for $80 \mathrm{~min}$.

The numerous porous calcium phosphate ceramics being investigated frequently have different sizes of macropores intentionally introduced for tissue ingrowth. In a ceramic structure, micropores are sometimes found to be more or less confined within the gross polycrystalline structure and are frequently localized at the grain boundaries. This microporosity could aid bioresorption by causing microscopic 'break-up' between bone and ceramics ${ }^{12,13}$. In this experiment, macro- and micro-pores could be generated and distributed uniformly in the porous glass ceramic. Moreover, macro- and micro-porosity could be controlled by the weight ratio of the additive. The relationship between porosity and amount of foaming agent added in the glass compact is shown in Figure 10. With the addition of $30 \%$ polyethylene glycol, the material heated at $900^{\circ} \mathrm{C}$ for $80 \mathrm{~min}$ could exhibit a porous structure with $43-46 \%$ porosity, macropores in the range $100-200 \mu \mathrm{m}$ and micropores of $3-5 \mu \mathrm{m}$.

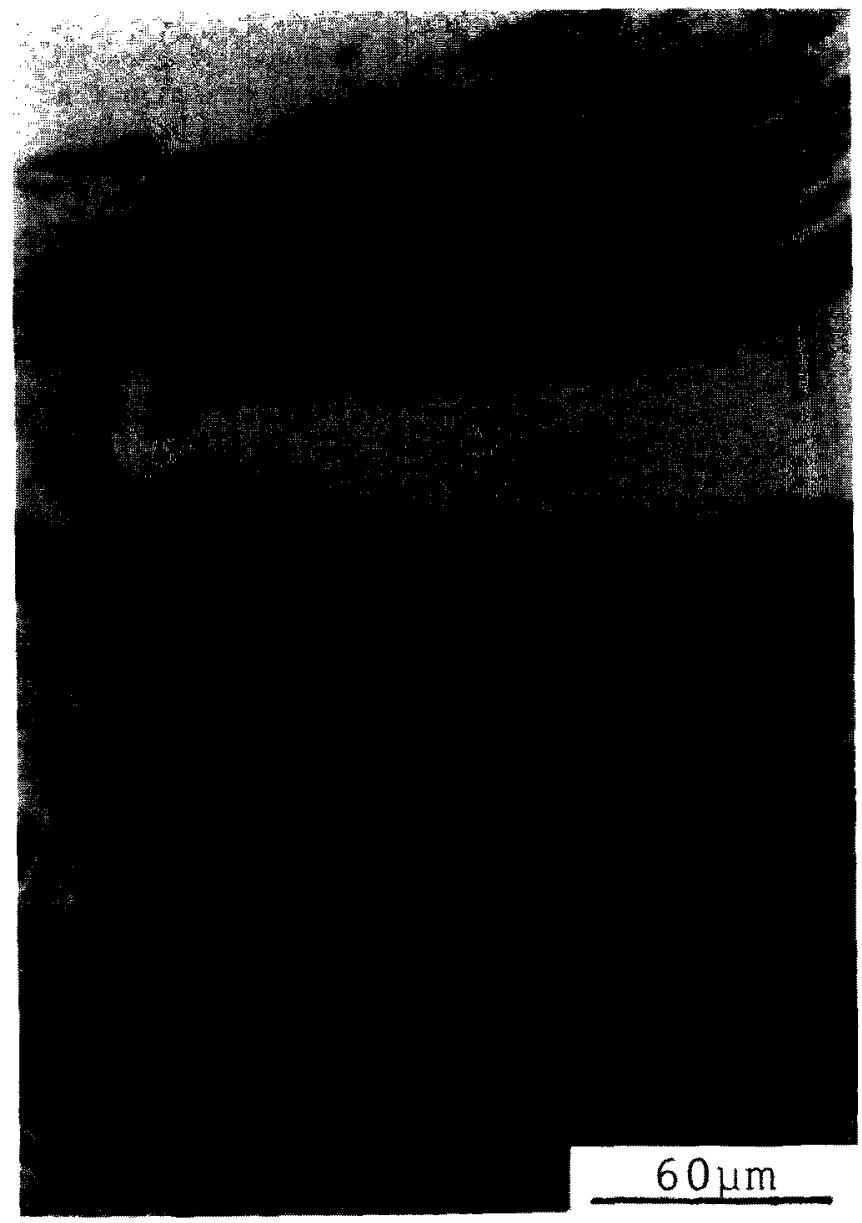

Figure 12 Optical micrograph of the rat shoulder test. BV = blood vessels; $\mathrm{IM}=$ implant site; $\mathrm{FB}=$ fibroblasts

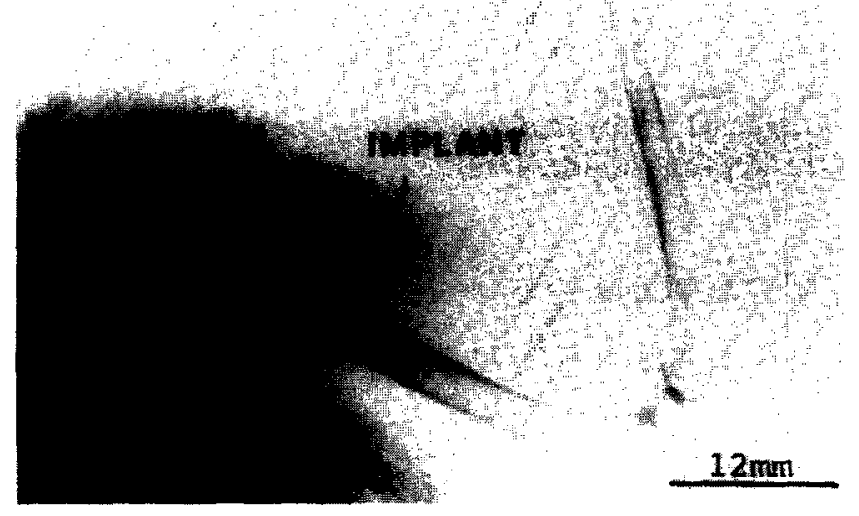

Figure $13 \mathrm{X}$-ray photograph of the implant in the rabbit femur

\section{Biocompatibility and histological evaluation}

Rat shoulder test:biocompatibility. This test is recog nized as a simple and rapid method for testing biomaterials. The X-ray photograph of the implant in the rats is shown in Figure 11. In the experiments, the rats recovered rapidly and their skin was not allergically sensitized. No inflammation or other pathology was observed, and vessels were growing around the implanted area (Figure 12). Both epithelial surfaces adjacent to each side of the implanted area were covered with newly growing fibroblasts. The glass ceramic used in this study presents good biocompatibility and an intimate affinity for biological texture ${ }^{x, 9}$.

Rabbit femur implant: histological evaluation. The X-ray photograph of the implant in the rabbit femur is shown in Figure 13 and indicated by a heavy arrow. After implantation for 3 months, the histologies of the interface between the material and new bone were the same and there was 'break-up' between the interface (Figure 14). The implant induced a tight chemical bond to the new ossteous tissue and no osteoclastic reaction cell necrosis or inflammation occurred, which could lead to loosening of the implants ${ }^{8-14,15}$. Based on these observations, the ability of a bond to bond directly to the surface of the

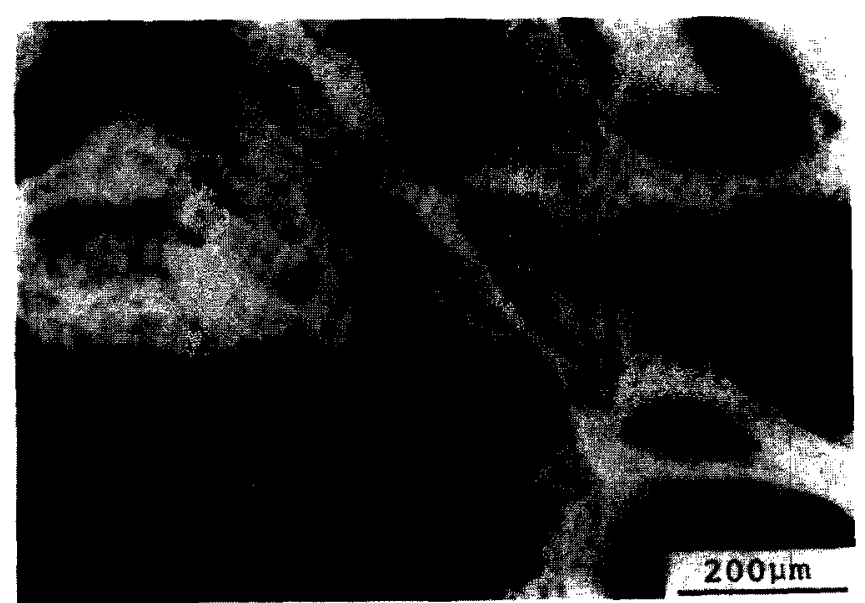

Figure 14 Optical micrograph of the histological evaluation. IM = implant; $\mathrm{NB}=$ new bone; $\mathrm{BU}=$ microscopic break-up between implant and new bone 
implant has now been demonstrated and the bonding substance observed on the surface of the implant is very similar in character to natural bone. The authors suggest that the excellent results obtained in these biomedical tests were due to the uniformly distributed macro- and micro-pore structures in the implant, which provided channels for bone ingrowth and microscopic break-up.

\section{CONCLUSIONS}

A porous bioglass ceramic of composition $\mathrm{Na}_{2} \mathrm{O} 12 \%$, $\mathrm{CaO} 28 \%, \mathrm{SiO}_{2} 50 \%, \mathrm{P}_{2} \mathrm{O}_{5} 10 \%$ and polyethylene glycol $400030 \%$, added as foaming agent, was prepared. After being heated at $900^{\circ} \mathrm{C}$ for $80 \mathrm{~min}$, the glass compact demonstrated a microstructure with macropores in the range $100-200 \mu \mathrm{m}$, micropores of $3-5 \mu \mathrm{m}$, and a porosity of $43-46 \%$.

Identified by tissue electron microscopy and $\mathrm{X}$-ray analysis, the crystalline phases precipitated in the material were $\beta-\mathrm{Ca}_{2} \mathrm{P}_{2} \mathrm{O}_{7}$ and $\mathrm{Na}_{2} \mathrm{Ca}_{3} \mathrm{Si}_{6} \mathrm{O}_{16}$.

The samples showed no cytotoxicity and exhibited an excellent tissue compatibility. Tight chemical bonding to the new bone was observed on the boneimplant interface. The porous bioglass ceramic prepared by the method described has been confirmed as a bone replacement material of considerable potential.

\section{REFERENCES}

1. Lin FH, Hon MH. A study on the sintering of $\beta$ tricalciumphosphate bioceramic. $J$ Med Eng ROC 1985; 5: $33-40$.

2. Lin FH, Hon MH. Sintering of $\beta$-tricalciumphosphate bioceramics with $\mathrm{Na}_{2} \mathrm{P}_{2} \mathrm{O}_{7} 10 \mathrm{H}_{2} \mathrm{O}$. J Mater Sci Lett 1987; 5: 331-3.

3. Carpenter PR, Campbell M, Rawlings RD, Rogers RS. Spherulitic growth of apatite in a glass-ceramic system. $J$ Mater Sci Lett 1986; 5: 1309-12.

4. Hench LL, Ethridge EC. Biomaterials, Interfacial Approach (Biophysics and Bioengineering Series). London: Academic Press, 1982; pp. 357-62.

5. Hench LL. In: Friechette VD, Lacourse WC, Burdick VL, eds. Physiological Factors at Bioceramic Interfaces, Surface and Interfaces of Glass and Ceramics. New York, NY, USA: Plenum Press, 1974: pp. 265-82.

6. de Groot K. Bioceramics consisting of calcium phosphate. Biomaterials 1980; 1: 45-50.

7. Klawitter JJ, Hulbert SF. Application of porous ceramics for the attachment of load bearing orthopedic application. J Biomed Mater Res Symp 1971; 2: 159-63.

8. Ferraro JW. Experimental evaluation of ceramic calcium phosphate as a substitute for bone rafts. Plast Reconstr Surg 1979; 63: 630-7.

9. Hon MH, Lin FH, Harn CL. A study of the properties and biocompatibility of hydroxylapatite. $J$ Min Metall $R O C$ 1988; 2: 143.

10. Dellemagne MJ, Melon J. Formation of brushite from the salts of bones and teeth. Soc Chim Biol 1945; 27: 597.

11. Kingery WD, Bowen HK, Uhlmann DR. Introduction to Ceramics. 2nd edn, New York, NY, USA: John Wiley \& Sons, Inc., 1976: p. 187.

12. Tomson MB, Nancolls GH. Mineralization kinetics: A constant composition approach. Science 1978; 200: 1059.

13. Tomson MB, Tomazig B, Everett M. The seeded growth of the calcium phosphate on dentine and predentine. J Dent Res 1977; 56: 1369-70.

14. Zhu P, Chen Z, Huang J, Chien P. Preparation of phosphate glass composite and their prosthetic application. J Non-Crystal Solid 1982; 52: 503-10.

15. Daculsi G, Passuti N, Martin S, Deudon C, Legeros RZ, Raher S. Macroporous calcium phosphate ceramics for long bone surgery in humans and dogs. Clinical and histological study. J Biomed Mater Res 1990; 24: 379-96. 